insist on extensive judicial review. ${ }^{83} \mathrm{It}$ is ironic that this, the fourth of the major thrusts of attack outlined above, is most likely to effect a change in the present practice. Critics of the practice would prefer to defeat it by exposing its baselessness or its outrageousness. No constitutional authority to regulate morals exists; no statutory authority to remove matter from the mail can be found; no restriction upon freedom of speech is tolerable. These arguments, abstractly persuasive, yield to the reality of history and precedent. Congress does in fact have power to decide-within limits-what matter will be carried in the mail. Section 1461 has authorized removal of obscene matter from the mail. Matter which is indeed obscene is not protected from congressional proscription by the first amendment. Only the procedure for determining obscenity may be successfully attacked; expansion of judicial review will relieve most of the pressure there. What probably will survive is censorship of an ill-definable collection of matter by the federal letter-carrying agency under the watchful eye of federal courts.

${ }^{83} \mathrm{It}$ is possible that judicial insistence upon extensive review will lead to relocation of the initial decision. If the majority of senders of matter found nonmailable appeal the administrative determination, the Post Office hearing will become meaningless. The relocation may take any of the forms suggested above.

\title{
STRIKE SUPERSENIORITY: VALID EXTENSION OF NLRB v. MACKAY RADIO AND TELEGRAPH OR VIOLATION OF SECTION 8(a)(3) OF THE NLRA?
}

In NLRB. v. Mackay Radio \& Telegraph Co., ${ }^{1}$ the Supreme Court ruled that an employer had the right permanently to replace economic strikers. ${ }^{2}$ Although the Court recognized that its ruling would indirectly inhibit employees in the exercise of their right to strike, ${ }^{3}$ the Court gave paramount weight to the right of the employer "to protect and continue his business by supplying places left

1304 U.S. 333 (1938).

2 The Mackay decision and other cases dealing with the reinstatement or discharge of strikers under the NLRA distinguish between current labor dispute strikes (often called economic strikes) and strikes brought about by an employer's unfair labor practice. The distinction originates in the wording of section 2(3) of the Act. The Mackay doctrine is limited to economic strikes. In the case of an unfair labor practice strike, the strikers are entitled to reinstatement notwithstanding the hiring of replacements during the strike, and their reinstatement must be unconditional, as though they had not been absent from work. NLRB v. Mackay Radio and Telegraph Co., 304 U.S. 333, 344-45 (1938); NLRB v. Sartorius \& Co., 140 F.2d 203, 206 (2d Cir. 1944); Polish National Alliance v. NLRB, 136 F.2d 175, 181 (7th Cir. 1943); Republic Steel Corp. v. NLRB, 114 F.2d 820, 821 (3d Cir. 1940).

${ }^{3}$ Section 7 of the National Labor Relations Act, 49 Stat. 452 (1935), as amended, 61 Stat. 140 (1947), 29 U.S.C. $\$ 157$ (1958), accords employees general but not unqualified protection to "engage in . . . concerted activities for the purpose of collective bargaining or other mutual aid or protection"; while section 2(3), 49 Stat. 450 (1935), as amended, 61 Stat. 137 (1947), 29 U.S.C. $\$ 152(3)$ (1958), preserves to strikers their protected status as employees under the Act. 
vacant by strikers."' In concluding that the employer was not bound to discharge replacements upon the termination of the strike the Court appeared to accept the position that the employer's right to maintain operations during a strike was given substance by his privilege to give replacements permanent tenure.

In the usual strike situation, a number of practical considerations may deter the employer from exercising his right to replace strikers. Among these are the unavailability of a sufficient number of skilled replacements, and the bitterness, and possibly violence, which may be touched off by replacement. One additional difficulty that has been asserted by employers is the reluctance of replacements to accept employment during the strike on terms which will, under the normal operation of the employer's seniority system, make the replacements the most vulnerable to lay-off in the event of any seasonal or other curtailment of the employer's work force following the strike.

To meet the latter difficulty, employers have devised so-called superseniority or strike seniority arrangements, and have urged that such arrangements are a legitimate means of preventing normal seniority from eroding the employer's right to replace. Under the typical superseniority plan, the employer adopts a new seniority list which reduces the seniority standing of strikers to below that of non-strikers and of new replacements hired during the strike. The crucial element in such an arrangement is that it makes reinstated strikers the most vulnerable to displacement in the event of a subsequent lay-off.

The National Labor Relations Board has invalidated all the superseniority plans on which it has ruled.5 In the later cases the Board appears, however, to have qualified its earlier position that superseniority arrangements were invalid per se. The Board's two most recent rulings have stressed the improper motive

4304 U.S. 333, 345 (1938). "Nor was it an unfair labor practice to replace the striking employees with others in an effort to carry on the business. Although section 13 of the act, 29 U.S.C.A. $\$ 163$, provides, 'Nothing in this Act [chapter] shall be construed so as to interfere with or impede or diminish in any way the right to strike,' it does not follow that an employer guilty of no act denounced by the statute, has lost the right to protect and continue his business by supplying places left vacant by strikers. And he is not bound to discharge those hired to fill the places of the strikers, upon the election of the latter to resume their employment, in order to create places for them. The assurance by respondent to those who accepted employment during the strike that if they so desired their places might be permanent was not an unfair labor practice, nor was it such to reinstate only so many of the strikers as there were vacant places to be filled." Id. at 345-46.

The Court in Mackay did not expressly state whether a valid offer of permanent tenure to replacements is limited to the situation where it is in fact necessary to induce otherwise unwilling workers to accept the positions vacated by the strikers. Neither did it make clear at what stage of the strike the employer's assurance of permanent tenure to those replacements who accepted employment must be made in order to bring it within the Mackay rule. But see notes 21 and 29 infra.

5 California Date Growers Assn., 118 N.L.R.B. 246 (1957); Mathieson Chemical Corp., 114 N.L.R.B. 486 (1955); Potlatch Forests, Inc., 87 N.L.R.B. 1193 (1949); St. Mary's Sewer Pipe Co., 54 N.L.R.B. 1226 (1944); Indiana Desk Co., 56 N.L.R.B. 76 (1944); Precision Castings Co., 48 N.L.R.B. 870 (1943); Paper, Calmenson and Co., 26 N.L.R.B. 553 (1940). 
behind the plan, rather than its inherently discriminatory character. ${ }^{6}$ The Courts of Appeals have, on the other hand, from the outset, shown a more favorable disposition toward superseniority plans, but they have, in the three cases in which they have ruled upon superseniority, ${ }^{7}$ differed on the requirements for a valid plan. The inconsistent judicial treatment may in part be accounted for by different interpretations of the Mackay doctrine, upon which all three decisions claim to be based.

This comment will first examine the decisions on superseniority in the light of the Mackay doctrine. It will then consider the desirability of this extension of the Mackay rule in the light of the statutory framework and its underlying policy.

\section{I}

In NLRB v. Potlatch Forests, ${ }^{8}$ the first case presenting the issue to the courts, the Mackay doctrine was extended to sanction the initiation and implementation of a strike superseniority plan. ${ }^{9}$ During a strike for higher wages, the employer was able to resume operations with some new employees and a large number of former strikers who had abandoned the strike. ${ }^{10}$ After the strike, the company reinstated the remaining strikers but altered its former seniority plan by instituting a strike superseniority policy. In the Board proceedings the employer claimed to have advocated superseniority in the course of the strike settlement negotiations, but the Board found that the new policy was in fact formulated shortly after the strike settlement agreement had been signed. ${ }^{11}$ More than a year later, the employer invoked this policy to justify the lay-off of two former strikers. The NLRB held ${ }^{12}$ that the superseniority policy was a violation of the

- California Date Growers Assn., supra note 5; Mathieson Chemical Corp., supra note 5.

${ }^{7}$ NLRB v. California Date Growers Assn., 259 F.2d 587 (9th Cir. 1958); Olin Mathieson Chemical Corp. v. NLRB, 232 F.2d 158 (4th Cir. 1956), aff'd per curiam, 352 U.S. 1020 (1957); NLRB v. Potlatch Forests, 189 F.2d 82 (9th Cir. 1951).

${ }^{8}$ Ibid.

2 For a statement of the disputed seniority plan in the Potlatch case, as embodied in the employer's "Return-to-Work Policy," see Potlatch Forests, Inc., 87 N.L.R.B. 1193, 1200-01 (1949).

${ }^{10}$ The court referred to the members of this group as "replacements" regardless of whether they were new workers or former strikers who crossed the picket lines. At the termination of the strike, the "replacements" numbered about 1750 out of a total normal working force of about 2600 . NLRB v. Potlatch Forests, supra note 7, at 83.

11 Portlatch Forests, Inc., supra note 9, at 1199-1200. See also note 24 infra.

12 Potlatch Forests, Inc., 87 N.L.R.B. 1193 (1949). In a prior case, General Electric Co., 80 N.L.R.B. 510, 513 (1948), the Board, in holding that the "tolling" of seniority rights of strikers during the period of a strike was an unfair labor practice, had said, "except to the extent that a striker may be replaced during an economic strike, his employment relationship cannot otherwise be severed or impaired because of his strike activity." The Board's holding in Pollatch was similarly in accord with its prior decisions on superseniority in the cases cited in note 5 sttpra. 
anti-discriminatory provisions of the National Labor Relations Act. ${ }^{13}$ The Board's petition for enforcement was, however, denied by the 9 th Circuit Court of Appeals, which held that, in the absence of evidence of a discriminatory motive, superseniority is a necessary concomitant of the right to hire replacements recognized in Mackay. ${ }^{14}$

A different result from that in Potlatch was reached by the Court of Appeals for the Fourth Circuit in Olin Mathieson Chemical Corp. v. NLRB. ${ }^{15}$ The em. ployer in that case instituted a superseniority plan shortly after the termination of an economic strike. Subsequently, seven employees were laid off in accordance with the new policy. The Board's holding that the policy violated sections 8(a)(1) and (3) of the Act ${ }^{16}$ was affirmed by the Court of Appeals for the Fourth Circuit, ${ }^{17}$ one judge dissenting. ${ }^{18}$

The employer in Olin Mathieson relied upon two contentions: first, that since Mackay permits the hiring of permanent replacements it also permits the less drastic action of depriving strikers of seniority for lay-off purposes; second, the employer contended that his conduct was specifically sanctioned by the 9th Circuit decision in Potlatch.19

The Court of Appeals brushed aside the first contention, stating that "The Mackay decision merely holds that an employer need not displace employees

13 "Sec. 8(a) It shall be an unfair labor practice for an employer-(1) to interfere with, restrain, or coerce employees in the exercise of the rights guaranteed in section 7 ; [see note 3 supra] ... (3) by discrimination in regard to hire or tenure of employment or any term or condition of employment to encourage or discourage membership in any labor organization. ..." 49 Stat. 452 (1935), as amended, 61 Stat. 140 (1947), 29 U.S.C. \$158(a)(1) and (3) (1958).

14 'In the instant case, therefore, the 'discrimination' between replacements and strikers is not an unfair labor practice despite a tendency to discourage union activities, because the benefit conferred upon the replacements is a benefit reasonably appropriate for the employer to confer in attempting 'to protect and continue his business by supplying places left vacant by strikers." " 189 F.2d 82, 86 (1951).

15232 F.2d 158 (4th Cir. 1956), aff'd per curiam, 352 U.S. 1020 (1957).

${ }^{16}$ Mathieson Chemical Corp., 114 N.I.R.B. 486 (1955). The Board referred briefly, in a footnote, to the 4 th Circuit decision in Potlatch, stating that that case was distinguishable upon the facts from the case before the Board. However, Acting Chairman Rogers and Member Murdock were "constrained, with due deference to that court, to disagree with the [court's] decision [in Pollatch] to the extent that it may conflict with the present finding." 114 N.L.R.B. 486,488, n.2. For a comparison of the relevant facts in the two cases see note 24 infra.

${ }^{17}$ In addition to a violation of $8(a)(3)$, the court found that "Olin's superseniority policy is in conflict with section 13 [49 Stat. 457 (1935), 29 U.S.C. $\$ 163$ (1958)] of the Act, providing that 'nothing in this Act, except as specifically provided for herein, shall be construed so as either to interfere with or impede or diminish in any way the right to strike...'" $232 \mathrm{~F} .2 \mathrm{~d}$ 158,160 (4th Cir. 1956). Incidental to the holding on the employer's strike seniority policy, the NLRB and the Court of Appeals found that the employer had refused to bargain collectively as required by section 8(a)(5) and (1) of the NLRA. Id. at 162.

${ }^{18} \mathrm{Ibid}$. Circuit Judge Soper dissented on the ground that the majority opinion was "in direct conflict with that of the Ninth Circuit in NLRB v. Potlatch Forests, 189 F.2d 82, which is not distinguishable in any essential feature. ..."

${ }^{19} 232$ F.2d 158, 160 (1956). 
hired during an economic strike to make room for returning strikers," ${ }^{20}$ and stressing that in contrast to Mackay, in Olin Mathieson the employer had promulgated his new policy after the strike, when it was no longer a necessary inducement to the workers to keep his plant in operation. ${ }^{21}$ The court then distinguished Potlatch principally on the ground that the employer in Potlatch had advocated strike seniority before the strike was settled, had adopted the policy at the time of settlement, and had consistently maintained that policy at all times thereafter. ${ }^{22}$ Although the court based the distinction on a statement of the court in Potlatch, ${ }^{23}$ the underlying facts do not appear to support a significant distinction between the two cases on the basis of the timing of the new policy. In neither case was the superseniority policy promulgated at a time when it could possibly have been used to induce replacements to fill the vacancies. ${ }^{24}$ The 4th Circuit court also observed that in Olin Mathieson the "replacements" were all old employees, while in Potlatch, the "replacements" had in. cluded both new and old employees, ${ }^{25}$ but it is unclear what influence, if any, this fact had on the Olin Mathieson decision. ${ }^{26}$

${ }^{20}$ Ibid.

21 After citing the Mackay dictum quoted in note 4 supra, the Court of Appeals went on to say, "But the situation before us is quite different. The strike was over, the strikers had returned to work. ... No promise, when they were employed, was made to the employees who remained at work during the strike or who returned to work before the end of the strike, that their employment would be permanent. Olin, after the strike, when there was no necessity for such action to keep its plant in operation, promulgated its superseniority policy in favor of the so-called 'loyal employees' and against those who returned to work after the strike had failed and was over. Olin was clearly penalizing the strikers for exercising their right to strike and was thereby clearly discouraging any exercise of this right in the future." Id. at 161. (Emphasis added.)

22 Ibid.

${ }^{23} 189$ F.2d at 86 (1951).

${ }_{24}$ The record did not disclose what promises Potlatch had made to the replacements. Ibid. Strike negotiations between Potlatch and the union were initiated on October 7, 1947, and on October 12,1947, an agreement was signed, containing the provision that "All former employees at Potlatch Forests, Inc. will return to work without discrimination." The strike was terminated on October 13. It was not until shortly after the strike settlement agreement was signed (apparently on October 14) that Potlatch determined upon and drafted its "Return-toWork Policy." Although it appears from the record that job protection for replacements was a topic discussed in the negotiations, it was disputed whether lay-off seniority was specifically touched upon, and certainly no agreement was reached on that subject. The company's new seniority policy does not appear to have been officially brought to the union's attention until June 1949. Potlatch Forests, Inc., 87 N.L.R.B. 1193, 1199-1201 (1949). However, the Board did stipulate that Potlatch had maintained its new policy without deviation from October 13, 1947. 189 F.2d at 84 .

In Olin Mathieson, the strike ended on March 17, 1954, and the new superseniority policy was adopted by the employer on April 2, 1954. Thus in neither case was the test of "necessity" enunciated by the court in Olin Mathieson (see note 21 sucpra) met, and there would not appear to be any material difference in the timing of the introduction of the new policies that would justify a differing result in the two cases on the basis of this issue, since in neither case was the strike seniority policy promulgated at a time when it could possibly have been used to induce replacements to fill the vacancies. See also note 18 supra.

232 F.2d at 168.

${ }^{26}$ In the only subsequent reference made to this fact in the opinion, the court said, "It seems 
In enforcing the decree of the Board on the basis of the employer's discriminatory motive, the 4th Circuit did not pass on the question of whether a super seniority plan would be valid if instituted under proper circumstances, at the correct time, and with no improper motivation. Nevertheless, the court did imply rather strongly that where the test of economic necessity is met, such a plan would be proper, ${ }^{27}$ and at no point in its opinion did it criticize the result in Potlatch. The Olin Mathieson decision did, however, squarely take issue with Judge Orr's statement in Potlatch ${ }^{28}$ that the timing and necessity of an offer of permanency under the Mackay doctrine are irrelevant. The majority in the Olin Mathieson case declared that such an offer was proper only where necessary to induce replacements to work during a strike. ${ }^{29}$

The Supreme Court granted certiorari in the Olin Mathieson ${ }^{30}$ case and the 4th Circuit decision was unanimously affirmed from the bench after the Court had heard only the employer's argument. ${ }^{31}$ The Court thus cast no light on the question whether Potlatch was a valid extension of the Mackay doctrine, and if so whether the distinctions made by the 4th Circuit with reference to the necessity, timing, and motive of the employer's promise were acceptable ones.

The most recent decision on superseniority, NLRB v. California Date Growers Assni. ${ }^{32}$ is of special interest since it was handed down by the 9th Circuit Court of Appeals, which had, seven years previously, decided the Potlatch case. ${ }^{33}$ In the

only fair to state that the record shows no past background of hostility towards the Unions on the part of Olin. Nor was there any discrimination between employees who did belong to the Unions and those who did not; for all the employees involved were Union men." 232 F.2d at 162.

${ }^{27}$ See note 21 supra.

28 "The Supreme Court . . . was concerned not so much with an explicit promise of permanent tenure as with the propriety of the employer's concern with that tenure." 189 F.2d at 86.

${ }^{29}$ The Olin Mathieson court said: "With this we disagree. With a strike in progress, the primary concern of the employer is to keep his plant in operation. It is then proper for an employer, who might be unable to procure replacements save upon a promise of permanent lenure, to promise such tenure to the replacements. But when the strike is over, when the plant is in operation, then the imposition of the superseniority policy in favor of the replacements and against the strikers is quite a different matter. That is the case before us." 232 F.2d at 161-62. (Emphasis added.) It should be noted that the court here, in sanctioning the making of a promise by the employer which meets the stipulated conditions, spoke in terms of permanent tenure, while in the negative part of its dictum, proscribing the making of a promise under the conditions of the case before it, the court spoke in terms of the imposition of a superseniority policy. Thus, unless "permanent tenure" can be read as synonymous with "superseniority," or the former can be said to necessarily include the latter (both of which are moot propositions) this dictum raises the question whether either the timing of the policy or the nature of the policy would in itself be sufficient to make it "quite a different matter" from the replacement of employees in Mackay. See also note 35 infra.

. 30352 U.S. 819 (1956). 31352 U.S. 1020 (1957).

32259 F.2d 587 (9th Cir. 1958).

${ }^{33}$ Neither Orr, C.J., who had written the opinion in Pollatch, nor Fee, D.J., who was on the Pollatch court, participated in this decision. The California Date Grociers court consisted of Bone, C.J., who wrote the opinion, Stephens, C.J., and Pope, C.J., the one member who had also sat on the court in the Potlatch decision. 
California Date Growers case, the employer had continued to operate during a brief strike by using non-striking employees and replacements. Upon termination of the strike, the employer had reinstated all workers for whom work was available, in accordance with a pre-existing seniority list. Subsequently, at the beginning of a new season, the employer publicized and adopted a superseniority list, and the new list was used for subsequent lay-offs of former strikers in the employer's highly seasonal business.

The employer's general manager testified before the trial examiner that when individual non-strikers and replacements had expressed concern over their job security during the strike, he told them that they had become "the nucleus of our work force" and "gave them the assurance they would be maintained if and when the strike was terminated." 34 The employer did not, however, advise either the non-strikers or the strikers of the superseniority policy until three months after the strike had terminated.

The Board, overruling the trial examiner, found that the superseniority policy was a violation of section 8(a)(1) and (3) of the Act. It held that the promises made by the employer to the non-strikers and replacements could not be interpreted as extending to changes in their seniority relative to that of former strikers, ${ }^{35}$ and that all the employer was entitled to do "under established law" (citing Mackay) was to refuse to reinstate any striker "permanently replaced" by a non-striker. ${ }^{36}$ The Board dismissed the employer's contention that his action was necessary for economic reasons and distinguished the case before it from Potlatch on the basis of the employer's delay in announcing the new seniority policy. ${ }^{37}$ The Board found that the timing of the policy together with other independent unfair labor practices ${ }^{38}$ of the employer showed that the employer was motivated by a desire to punish the strikers.

In enforcing the Board's order, ${ }^{39}$ the 9 th Circuit court relied on Mackay and

${ }^{34}$ California Date Growers Assn., 118 N.L.R.B. 246, 262 (1957).

${ }^{35}$ The distinction made by the Board between a promise of permanent tenure and a promise of superseniority lends support to the point made in note 29 supra.

${ }^{36} 118$ N.L.R.B. at 249-50. "This is not to say, however, that the Respondent after the strike was over could go further than that and reduce the seniority of the returning strikers, who had not been replaced, to punish them because they had engaged in protected concerted activity." Id. at 250 .

${ }^{3 t} I d$. at 248-51. The Board, on the basis of the above differentiation, found it unnecessary to pass on the 9th Circuit's decision in Potlatch. However, Member Murdock noted his disagreement with the court's position in Potlatch, and stated that, in accordance with the Board's decision in Potlatch, he would rule that the employer's superseniority policy was unlawful without regard to whether it was adopted during or after the strike. Cf. note 16 supra.

${ }^{38}$ Here, as in Olin Mathieson (see note 17 supra), the Board found that the employer had refused to bargain collectively in violation of section 8(a) (5) and (1) of the Act, and went on to say, "Such clear and unwarranted violations of the Act cannot be ignored in assessing Respondent's motivation for an additional act of discrimination, occuring exactly at the same time and by exactly the same means." 118 N.L.R.B. at 249.

${ }^{39}$ The order was also modified as too broad for reasons not relevant to the problem here being discussed. 259 F.2d at 591 . 
Potlatch for the proposition that "the actions taken by [the employer] in the instant case do not constitute unfair labor practices in and of themselves. Such actions in particular situations may be perfectly permissible within the act." 40 The court also cited Olin Mathieson and Potlatch for the proposition that "the motive of the employer in carrying out these actions becomes the controlling factor." ${ }^{41}$ It went on to stress that even some members of the employer's management had not been aware of the new policy until long after the termination of the strike, and that nowhere on the record was it indicated that the employer found it necessary to promise the non-strikers superseniority in order to continue its operations. The court distinguished Pollatch on the ground that in that case the employer had made his position "clear and open before termination of the strike." 42 It concluded that there was substantial evidence on the record to support the Board's finding of a discriminatory and punitive motive "to discourage by this means further activity by those strikers or other employees in behalf of the Union, all in violation of [section] 8(a)(3) and (1) of the Act." ${ }^{43}$

The 9th Circuit Court in California Date Growers thus reaffirmed the proposition, announced in Potlatch, that superseniority, where not punitively motivated, was a logical extension of the Mackay rule and therefore not unlawful per se. The court's dictum that "At no place in the record is it indicated that [the employer] found it necessary to promise the non-striking employees seniority superior to that of the strikers in order to continue its operations"44 does, however, indicate a recognition of the "necessity" test implied in the Olin Mathieson opinion. The California Date Growers' court thus impliedly repudiated the notion, advanced in Potlatch, of "propriety of the employer's concern with" 45 the status of the replacements at a later date when a promise of superseniority was no longer necessary to insure the continuation of operations.

II

In the light of the divergent results reached and the different considerations stressed in Olin Mathieson, and California Date Growers as compared to Potlatch, to what extent may Potlatch be said to be the accepted law today? Although the courts in both Olin Mathieson and California Date Growers distinguished Potlatch on the facts, there would appear to be little doubt that they accepted the general proposition that superseniority when imposed under proper circumstances and without discriminatory motive, is a valid extension of the Mackay doctrine. The 9th Circuit, in Califormia Date Growers, expressly reaffirmed this aspect of the Potlatch holding. ${ }^{46}$ The 4th Circuit in Olin Mathieson strongly implied the acceptability of that position, ${ }^{47}$ and it did not in any way criticize the

40 Id. at 589.

41 Ibid.

4 Ibid. But see text at notes 11 and 24 supra. ${ }_{43}^{\prime} I d$. at 590.
$4 I d$. at 589.

${ }^{45}$ See note 28 supra.

${ }^{46}$ See text at note 40 supra.

${ }^{17}$ See note 24 supra. 
result in Potlatch; and even the NLRB appears to have retreated from its firm stand in Potlatch and its predecessors against superseniority as unlawful per se. ${ }^{48}$ The merits of this extension of the Mackay doctrine will be examined below. Since, however, the courts do not appear to be prepared to reject superseniority as unlawful per se, it is appropriate first to examine the limitations on its application, which are suggested by the cases.

The considerations emphasized in the three opinions are: (1) "necessity"; (2) timing of notification of strikers and non-strikers; (3) "propriety"; and (4) motive.

It is submitted that the only criterion for the legality of superseniority plans acceptable under and consistent with the Mackay doctrine, if indeed that doctrine can validly be extended to sanction such plans, is the test of "necessity." The Supreme Court, in Mackay, speaking of the employer's "right to protect and continue his business by supplying places left vacant by strikers" ${ }^{19}$ held that this legitimate economic interest of the employer warranted an incidental infringement of the statutory protection afforded to strikers by the Act. The Court did not suggest that the employer might use the grant of permanent tenure to reward replacements or to penalize strikers. Indeed, such employer action would appear to violate section 8(a)(3).

The employer's right in Mackay to hire replacements rested solely upon his right to carry on his business during the strike. Assurance of permanent tenure to replacements ${ }^{50}$ was held to be proper, despite the fact that it was in derogation of the strikers' rights, because it was in furtherance of, and reasonably necessary for, the carrying on of his business operations. Thus, to allow an employer to use permanent tenure or superseniority as a weapon against striking employees or to reward non-strikers would clearly be beyond the scope of the Mackay doctrine. Only where the employer can prove that promises of permanent tenure or superseniority to replacements were reasonably necessary to induce the replacements to cross picket lines during a strike, and that such promises were made at such a time that they would act as an inducement, should the employer be allowed to adopt and implement a superseniority plan.

The timing of notification to non-strikers of the initiation of the superseniority plan would appear to have no significance independent of the requirement that a promise or offer be made at a time when it is necessary to induce replacements to keep the employer's plant in operation during the strike.

The courts in both Olin Mathieson and California Date Growers distinguished

${ }^{18}$ Compare notes 12, 16 and 37 supra. In Potlatch, the Board had said, "There can be no doubt, and it is now well settled, that a seniority policy which classifies employees according to whether they had worked during a strike, or had not, to the detriment of the relative seniority standings of those who had not, discriminatorily and illegally impairs the employment relationship of those who had exercised their right under the Act to engage in concerted activities." 87 N.L.R.B. at 1210 (1949).

19 304 U.S. 333, 345-46 (1938), quoted in full note 4 supra.

50 Ibid. 
Pollatch on the ground that Potlatch had advocated superseniority prior to the termination of the strike. ${ }^{51}$ But in Potlatch, so far as the Board's opinion indicates, the employer had made no promise to the replacements prior to the termination of the strike. The only stage at which the issue of lay-off superseniority may have been raised prior to the strike settlement (and even this point was disputed), was in the course of negotiations with the strikers' representatives.52

It is difficult to see why the timing of the announcement of the policy to the strikers, rather than to replacements, deserves the importance attached to it in the three opinions. ${ }^{53}$ Both the equitable consideration that the strikers should be notified of the terms upon which they are returning to work and the employer's statutory obligation to bargain in good faith with the strikers' representatives $^{54}$ would, however, appear to call for a full disclosure of the employer's proposed policy to the strikers or their representatives before the termination of the strike.

The "propriety" test enunciated in Pollatch would appear to rest on an untenable interpretation ${ }^{55}$ of $M a c k a y$ as holding that whether or not the employer did in fact promise permanent tenure to the replacements, he might at a later date extend such tenure, provided that his concern with such tenure was "proper." Although in Potlatch the new policy was stated by the court to have been advocated before the strike was settled and adopted at the time of settlement $t^{56}$ the court's dictum was not limited to such a situation. Furthermore, the court did not elaborate on what constituted "proper" concern on the part of the employer, thereby making this an extremely tenuous and broad criterion for the imposition of a superseniority plan. The defects inherent in this criterion, and its rejection in Olin Mathieson and California Date Growers would appear to justify its elimination from further consideration as a statement of either what the law is or what it should be.

The motive of the employer in initiating a superseniority plan is an element emphasized in all three opinions. In Potlatch, the court found no discriminatory motive outside that inherent in superseniority. ${ }^{57}$ In Olin Mathieson and Califor-

51 See text at notes 22,42 supra.

52 See note 24 supra.

${ }^{53}$ Auterican Bar Assocjation, 1959 Report of the CoNamtiee on Developuent of the LAW UNDER NATIONAL LABOR RELATIONS ACT 42 (1959).

${ }^{34}$ Cf. NLRB v. Truitt Mfg. Co., 351 U.S. 149 (1956); NLRB v. Scharfstein, 209 F.2d 261 (6th Cir. 1953).

${ }^{35}$ See notes 28,29 supra.

${ }^{56}$ Butt see note 24 supra.

${ }^{57}$ See note 14 supra. The Court did say that, "Presumably, the Board impliedly found that the true purpose motivating Potlatch's adoption of the 'strike seniority policy' was a desire to penalize those members of the Union who had most persistently asserted the Union's demands," but it went on to hold that "the conclusion that Potlatch must have realized the inevitable consequences of the policy" was not enough to support a finding of discriminatory motive where the employer had acted within his rights under the Mackay doctrine. NLRB v. Potlatch Forests, 189 F.2d 82, 86 (1951). 
nia Date Growers, on the other hand, the motive of the employer was the ultimate factor upon which the courts' and the Board's decisions rested.58

The relevance of the motivation of the employer in cases of alleged discrimination arising under the LMRA has been consistently recognized by the courts. ${ }^{59}$ Specific evidence of a discriminatory or punitive motive may serve to invalidate a superseniority plan which fully meets the "necessity" test. But, absent a finding of improper motive, the necessity of the employer's action under the circumstances should be the controlling factor. Mere absence of specific evidence of a discriminatory motive should not in itself be sufficient to legalize a superseniority plan. Unless the necessity test is first met, an inevitable consequence of superseniority is to punish the strikers without thereby furthering the legitimate objective, sanctioned in Mackay, of maintaining the employer's continuity of operations during the strike.

\section{III}

The foregoing discussion has been predicated upon an acceptance of superseniority as a valid extension of Mackay. The propriety of such an extension is, however, itself subject to challenge as repugnant to the policy embodied in the statute. ${ }^{60}$

A basic objective of the original Wagner Act was to insure the rights of workers to engage in concerted activities and to endow unions with full collective bargaining powers, thereby redressing the bargaining disadvantage attributed to the individual employees. ${ }^{61}$ Although the Taft-Hartley amendments show that the interests of the employer and those of society in general were not to be neglected, ${ }^{62}$ the protection of employees exercising their right to engage in concerted activities from employer interference and discrimination is still a dominant policy of the Act.

The Mackay doctrine was itself a limitation upon the broad protective policy reflected in the Act, and it should, therefore, be strictly construed. In Mackay, the Supreme Court held that an employer, in order to carry on his business during a strike, could lawfully give "assurance ... to those who accepted employment during the strike that ... their places might be permanent.."63 This meant that the employer was "not bound to discharge those hired to fill the places of

${ }^{58}$ See text at notes 27,43 supra.

${ }^{50}$ NLRB v. Jones and Laughlin Steel Corp., 301 U.S. 1 (1937); Officers' Union of Commercial Telegraphers Union v. NLRB, 347 U.S. 17 (1954).

${ }^{60} \mathrm{Law}$ review comment has been almost unanimously critical of such an extension of the Mackay doctrine. See 4 Stan. L. Rev. 151 (1951); 6 Rutgers L. Rev. 470 (1952); 30 Texas L. REv. 776 (1952); 9 WASH. \& LeE L. REv. 115 (1952); 42 VA. L. REv. 836 (1956); 6 DUkE B.J. 143 (1957); 70 HARv. L. REv. 737 (1957); 52 Nw. U. L. REv. 122 (1957). For more favorable or non-committal comment see 100 U. PA. I. REv. 287 (1951); 41 MrNv. L. REV. 482 (1957).

61 H.R. REP. No. 972, 74th Cong., 1st Sess. 6-8, 13-17 (1935).

${ }^{62}$ S. Rer. No. 105, 80th Cong., 1st Sess. (1947); and H.R. Rep. No. 245, 80th Cong., 1st Sess. 3-6 (1947).

63304 U.S. 333, 345 (1938). 
strikers, upon the election of the latter to resume their employment." ${ }^{164}$ But from the proposition that replacements need not be dislodged by returning strikers, it does not necessarily follow that replacements should acquire rights superior to those of strikers who are reinstated. Proponents of superseniority urge that it is less drastic than outright replacement of employees, and hence that it is proper for an employer to take the less drastic action of depriving strikers of seniority for lay-off purposes in order to accomplish the same objective of business continuity. ${ }^{65}$ This, however, not only ignores the practical consideration that the employer is seldom able to find a sufficient number of skilled replacements to replace all the strikers, but also fails to take account of the protection that section $2(3)^{66}$ affords to the continuity of the employee's status. Under Mackay, the employer can affect the status only of a striker who has in fact been replaced by another worker ${ }^{67}$ on the theory that the termination of the strike strips the replaced striker of his rights as an employee under section 2(3). Thus while the employer's right to replace under Mackay acts as a serious threat to the limited, and usually very small, number of employees who have actually been replaced by outsiders, the threat of a loss of seniority weighs heavily against all strikers and, therefore, constitutes a far more potent weapon in the hands of the employer against unions in general and more specifically against the worker's right to strike.

It has also been suggested that the replacements have a right to demand strike seniority "as a guaranty that the employer will not accomplish the same result [as the firing of replacements upon the return of the strikers] by his lay-off seniority system." ${ }^{68}$ This argument could, however, hardly be applied to socalled replacements who are in fact old employees; and, furthermore, since the possibility of future lay-off in the event of a curtailment of operations is a problem common to all new employees, it is highly doubtful whether replacements should be given such greatly preferential treatment merely because they were hired at the time of the strike. Concededly, the granting of preferential seniority to replacements might make it easier for the employer to attract replacements to protect his business. However, when the harm to the employees is weighed against the protection to which the employer is entitled under the Act, the extension of the Mackay doctrine to superseniority plans clearly appears to be unwarranted as it tends dangerously to undermine the strike as a collective bargaining device. ${ }^{69}$

${ }^{6}$ Ibid.

${ }^{65}$ See text at note 19 supra.

${ }^{6 B}$ Note 3 supra.

${ }^{67}$ Home Beneficial Life Insurance Co. v. NLRB, 159 F.2d 280 (4th Cir. 1947), cert. denied, 332 U.S. 758 (1947); NLRB v. Poultrymen's Service Corp., 138 F.2d 204, 211 (3rd Cir. 1943); Firth Carpet Co. v. NLRB, 129 F.2d 633, 636 (2d Cir. 1942).

${ }_{68} 100$ U. PA. L. REv. 287, 289 (1951).

${ }^{69}$ Likewise, the offering of wages to replacements higher than those offered the strikers may constitute an unfair labor practice. Cf. NLRB v. Crompton Mills, 337 U.S. 217 (1949). However, in Pacific Gamble Robinson Co. v. NLRB, 186 F.2d 106 (6th Cir. 1950), the 6th Circuit Court of Appeals appears to have held that such action was permissible, at least where the difference was not substantial. See 70 HARV. L. REv. 737, 738 (1957). 
In addition to the policy arguments already presented against the adoption of the Mackay rule in superseniority cases, the decisions on the subject are open to serious question with regard to their treatment of newly hired replacements and old employees who crossed the picket lines as one group. Only new employees were afforded the protective cloak of "replacements" in the Mackay case. No reasonable interpretation of the dictum in the Mackay case would appear to justify the inclusion of "old" employees in that category, since they can hardly be said to have "replaced" strikers and since the circumstances of necessary and proper inducement would not appear to be present in the case of old employees who had crossed the picket lines. ${ }^{70}$ Furthermore, the inclusion of old employees within the category of replacements not only sharply increases the threat to the union and to the strikers since, as a practical matter, adequate new replacements are generally not available, but it also tends to seriously undermine the strikers' solidarity, since the first strikers to "break ranks" and return to work will benefit at the expense of their fellow-workers who remain out on strike. ${ }^{71}$ These additional factors, which tend to make superseniority a more potent weapon against strikers in the hands of the employer, were not present in the Mackay case, and therefore their effect on the balance of power between the employer and the union was not considered by the Supreme Court in that case. Thus to say that the legality of superseniority plans naturally flows from the reasoning in the Mackay decision is a dangerous over-simplification, and, in effect, an evasion of the necessity for a careful reappraisal of the balancing of interests involved.

On the other hand, if superseniority were limited to new replacements, ${ }^{72}$ thereby avoiding the thrust of the arguments just made, this would place new employees as a group ahead both of the non-striking and the striking old employees, which would clearly be an unsatisfactory result for both the employer and the employees. And, even if each new replacement were offered the seniority

${ }^{70}$ Indeed, the proposition that an employer may induce strikers to return to work by offering them greater seniority than full-term strikers is directly counter to holdings of the NLRB and some of the courts of appeals that an employer violates section 8(a)(1) of the Act when he resorts to threats or promises of benefit to coerce workers to return to work, and, also, that he violates section $8(a)(5)$ when such solicitation has been conducted under circumstances and in a manner reasonably calculated to undermine the strikers' bargaining representatives. See, e.g., The Texas Co., 93 N.L.R.B. 1358, 1360-62 (1951); American Rubber Products Corp. v. NLRB, 214 F.2d 47, 54 (7th Cir. 1954); NLRB v. James Thompson \& Co., 208 F.2d 743, 74849 (2nd Cir. 1953); NLRB v. Bradley Washfountain Co., 192 F.2d 144, 152-54 (7th Cir. 1951).

71 Here again, as in the case of outright replacement, the resulting antagonism and bad feeling aroused both between the two groups of employees and toward the employer, with their frequent long-term effects on the cohesiveness and efficiency of the working force as a team after the settlement of the strike, probably often act to deter the employer from attempting to impose a superseniority plan where he might otherwise be tempted to do so. Another deterring factor is the fact that often the strikers are more skilled and thus more valuable to the employer than the replacements.

72 For a somewhat more extended discussion of limited superseniority plans and their inherent defects see $52 \mathrm{Nw}$. U. L. REv. 122, 128-29 (1957). 
status of the employee whom he was replacing, this might again result in some new employees receiving greater seniority than some non-striking old employees. Similarly, any attempt to remedy this last defect by giving non-striking old employees preference over new replacements would necessarily be open to the objections already voiced ${ }^{73}$ with regard to inducing and rewarding non-striking old employees at the expense of the strikers. Thus, in addition to the strong policy arguments that may be made against superseniority plans, it would appear that such plans, if critically analyzed in the light of the equities and the practical problems involved, also pose great, if not insuperable, technical and legal problems of implementation.

The foregoing analysis suggests that strike superseniority, with its tendency seriously to undermine the strike as a collective bargaining device, does not qualify as a valid extension of the employer's rights under the Mackay rule. However, given the readiness of the courts to accept strike superseniority as not unlawful per se, and pending an authoritative ruling by the Supreme Court on the subject, it is submitted that its application should be limited to cases where the employer is able to show reasonable economic necessity and actual inducement of replacements as justification for the initiation of such a plan, and where he has informed the strikers of the plan prior to the termination of the strike.

${ }^{73}$ See text at note 69 sipra.

\section{APPLICATION OF THE DOCTRINE OF RES JUDICATA TO SUCCESSIVE IN PERSONAM AND IN REM ACTIONS IN ADMIRALTY}

A maritime lienor enforces his claim by a libel in rem against the vessel. ${ }^{1}$ If he also has a personal claim against the owner of the vessel for the same injury, as in cases of collision, he may proceed in personam, either at law or in admiralty. ${ }^{2} \mathrm{It}$ is generally held that the remedies in personam and in rem are cumulative rather than in the alternative. ${ }^{3}$

1 The Moses Taylor, 71 U.S. (4 Wall.) 411 (1866); The Hine v. Trevor, 71 U.S. (4 Wall.) 555 (1866). For an excellent discussion of the sources of maritime liens, emphasizing the role of the Federal Maritime Lien Act, see GIIMORE \& BLACK, ADMIrRALTY \$§ 9-30 to 9-43 (1954).

2 See GIIMORE \& BLACK, ADMrralTY $\$ 1-13$ (1954), for an interesting analysis of the principles involved in the problem of dual jurisdiction, including citation of the pertinent cases. Of particular importance to this question is the so-called saving clause, 28 U.S.C.A. $\$ 1333$ : "The district courts shall have original jurisdiction, exclusive of the courts of the states, of: (1) Any civil case of admiralty or maritime jurisdiction, saving to suitors in all cases all other remedies to which they are otherwise entitled."

${ }^{3}$ The Golden Gate, 52 F.2d 397 (9th Cir. 1931); The Grand Republic, 138 Fed. 615 (E.D.N.Y. 1905), aff'd, 144 Fed. 1022 (2d Cir. 1906); Morris v. Bartlett, 108 Fed. 675 (3d Cir. 1901); Rogers v. The Reliance, 20 Fed. Cas. 1125 (No. 12,019) (C.C.D. La. 1872); Baun v. The Ethel G., 125 F. Supp. 835 (D. Alaska 1954); The Henry S., 4 F. Supp. 953 (E.D. Va. 1933); The Eastern Shore, 24 F.2d 443 (D. Md. 1928); Everett v. United States, 277 Fed. 256 